ISSN 0975-3311

Ushus JBMgt, 9, 2 (2010) 1-18

ISSN 0975-3311 | https://doi.org/10.12725/ujbm.17.1

\title{
THE IMPACT OF POWER BASES AND LEADERSHIP STRATEGIES ADOPTED BY MANAGERS ON INFORMATION TECHNOLOGY EMPLOYEES
}

\author{
Harold Andrew Patrick*
}

\section{ABSTRACT}

The present investigation focused on power bases and its impact on leadership strategies of IT managers and its impact. The dependent variable was leadership strategies and its impact and independent variable was power bases adopted by IT managers. Three standardized tools were adopted to collect data. 515 respondents for this study representing 87 Indian, Indian multinational and multinational IT companies were surveyed. The hypotheses were tested. The detail findings, conclusions, implications and suggestions have been discussed.

Keywords: Power bases, Prescriptive Strategies, Restrictive Strategies, Aggressive Impact, Constructive Impact, Passive Impact.

\footnotetext{
* Christ University, Institute of Management, haroldpatrick@christuniversity.in
} 


\section{Introduction}

Power is one of the most important motives that individuals strive for. Power and influence can be studied from various angles. No organization is devoid of power. Organizations can be perceived as politically negotiated orders. Organizational charts are mainly provided to describe the formal allocation of power that is positional power, to job titles. They also indicate other functions such as collective and individual power, how it is attained. Power is an inescapable part of management (Torrington, Weightman, \& Johns, 1985). It is also a critical element for a political analysis of organizations. No effective manager can manage without understanding and using power in an appropriate manner, especially to get any job done. The use or misuse of power could be analysed in two segments a) For personal effectiveness or and b) for organizational effectiveness. Most conceptions are based on Weber's' (1947) classic definition that, "Power is a probability that one action within a social relationship will be in a position to carry out his own will, despite the resistance and regardless of the basis on which this probability rests.

Leadership behavior: An organization has the greatest chance of being successful when all employees work toward achieving its goal. Since leadership involves the exercise of influence by one person over others, the quality of leadership is a critical determinant of organizational and managerial behavior.

Leadership studies can be classified as Trait, Behavioral, Contingency, and Transformational. Early research assumed that the primary source of leadership effectiveness stems from personal traits of the leaders. Later research focused on leader behavior and sought to explain the relationship between what the leaders did and how the employees reacted, both emotionally and behaviorally. Contingency models focus on leadership style in different environments. Latest concepts in leadership include transactional, transformational, charismatic, ideal leadership and so on.

'Leadership is the ability to inspire confidence and support among the people who are needed to achieve organizational goals', Kim \& Mauborgne (1992). The leader has more than one person to lead, has the power to affect others and has a goal to attain. Several other representative definitions of leadership are as follows: Bass (1990). 
- Interpersonal influence directed through communication, toward goal attainment.

- The influential increment over and above mechanical compliance with directions and orders.

- An act that causes others to act or respond in a shared direction.

- The art of influencing people by persuasion or example to follow a line of action.

- The principal dynamic force that motivates and coordinates the organization in the accomplishment of its objectives.

Kotter (1990) observed that managers must know how to lead as well as manage. The key point in differentiating between leadership and management is the idea that employees willingly follow leaders because they want to, not because they have to. Managerial behavior in information technology organizations is affected by power processes and leadership behavior.

Contrasting leadership and power processes: Leadership behavior and power processes are closely related. Leaders use power as a means of attaining group goals. Leaders achieve goals and power is a means of facilitating their achievements. The differences between the two are related to (A) Goal compatibility - power does not require goal compatibility but merely dependence. Leadership requires some congruence between the goals of the leader and those being led. (B) Direction of influence of one's subordinates - it minimizes the importance of lateral and upward influence patterns. (C) Leadership research emphasis style and research on power has tended to encompass a broader area and focus on tactic for gaining compliance.

Power, politics and leadership: To acquire and retain power, a leader must skillfully use organizational politics - informal approaches to gaining power through means other than merit or luck. Organizational power is derived from many sources and can also stem from ownership, providing resources, capitalizing upon opportunity, and being close to power.

Leaders who intend on increasing their power should develop a plan which must include setting a goal, measuring the cost effectiveness of politicking, 
conducting power analyses of powerful people, and analyzing what type of politics is played at the top.

To make effective use of organizational politics, leaders must be aware of specific political tactics and strategies. Techniques aimed at ethical means of gaining power, building relationships, and avoiding political blunders should be encouraged through effective leadership. Unethical means such, as embrace-or-demolish strategy must be discouraged if I.T organizations want to increase their effectiveness in goal achievement.

Conger's (1989) research suggested that empowering practices by leader include providing a positive emotional atmosphere, rewarding and encouraging in visible and personal ways, expressing confidence, fostering initiative and responsibility, and building on success, praising initiative, and practicing super leadership.

The Role of Power in Leadership: Power plays a major role in the interactions occurring in organizational life. Power over others is intertwined with an understanding of leadership processes. Yet, despite the relevance of power to organizations and the understanding of the leadership process, research studies of power and leadership are not well integrated (Hollander \& Offermann, 1990). McClelland (1970) demonstrated how effective leadership could be instrumental in promoting social disaster.

Research on power in organizations has generally been based on simplistic notions of power which appear to render it amenable to empirical investigation, for the most part of a quantitative nature despite the impracticability's of quantitative solutions to the problem. The tendency has been to examine the intentional and overt behaviour of individuals and groups and the effects of power. Pfeffer's (1981) review of research on power notes the focus of most studies of power in organizations is "on hierarchical power, the power of supervisors over subordinates, or bosses over employees" (p. 3), power which serves functionalist imperatives.

\section{Design of the Study}

Need and rationale for the study: There are a few studies investigating these variables and its relationships have not been clearly established in the Indian context. Therefore the study gains importance. Business in Indian has 
predicted that the Indian I.T sector is a fast growing developing and maturing sector in its contribution to the Indian economy. Thus the present study becomes more meaningful as it needs to provide some new insights in the knowledge worker context.

The importance of power in organization needs to be overemphasized, as it is one of the essential components of practically in every organization. A clear understanding of organizations requires a thorough analysis of power as one of its central features. Since power is often viewed negatively, there has been a strong tendency to obscure it. Zaleznick (1970) "....... Executives are reluctant to acknowledge the place of power both in individual and in the organizational relationships. Some managers withdraw into the safety of organizational logic.

Managers regularly acquire and use power. They do so deliberately and consciously as well as intuitively and unconsciously. Power oriented behaviour has an impact on managerial career progress, on the job performance, on organizational effectiveness, and on the lives of many people.

Knowing the all-pervasive nature of power within organizations very little has been written on power and its relationship to management. Neither popular textbook on management and organizational behaviour, or published articles has sufficiently dealt with power processes in organizations.

Leadership and power do differ in goal compatibility, direction of influence on one's subordinates and research emphasis as mentioned earlier. This study attempts to reduce drastically these differences and focus on the positives of power and leadership processes to be exercised by managers for enhancing organizational effectiveness.

This study is an attempt to contribute afresh with a new perspective to the field of behavioural sciences with special reference to power processes, leadership and its behavioral implications of managers in information technology organizations. It is also an earnest attempt to bridge the gap especially in this area by highlighting the relevance and importance of power processes and leadership to management, individual, and organizational effectiveness and hoping this study will initiate a series of serious and productive discussions on the subject. 


\section{Aims and Objectives}

- To understand how power bases is utilized by managers and its effect on employees' in I.T organizations.

- To understand leadership strategies adopted by managers in I.T organizations.

- To understand the power orientations of managers in I.T organizations.

- To find out the impact power bases have on I.T employees.

- To find out the impact leadership strategies have on I.T employees.

\section{Sample Size}

The research was carried out on a sample size of 100 respondents. The respondents were drawn from 16 Information Technology organizations which are fairly representative of the population and at all three managerial levels - junior level executives, manager level and senior level managers.

\section{Instruments for Collecting Data}

Measurement models: Based on the objectives and the measurement model of the study the following tools were adopted to gather data from the sample. The Cronbach's Alpha reliability statistics for all items for the above instruments was .962 .

1. Managerial power variables: For this research, managerial power was assessed by using French and Raven's (1959) power-based taxonomy. French and Raven's (1959) bases of power is measured using a modified version of Hinkin and Schriesheim's (1989) 25-item power scale, as adapted by Nesler, Aguinis, Quigley and Tedeschi (1993). The scale employs a nine-point response scale ( $1=$ Disagree; $9=$ Agree), and consists of six subscales: coercive power, expert power, legitimate power, referent power, reward power and credibility. Based on the results of a CFA supporting five power factors, these items were used to create five composite scales: coercive power ( 3 items, á $=0.71$ ); expert power (4 items, á $=0.76$ ); legitimate power (4 items, á $=0.81)$; referent 
power ( 4 items, á $=0.89$ ); reward power ( 3 items, á $=0.77$ ); and credibility ( 5 items, $a=0.70)$. The nine-point scale was reduced to a seven-point scale ( $1=$ Disagree; $7=$ Agree) and used for the present study.

2. Leadership Strategies and Impact on others: For this research, a standardized instrument Leadership/Impact $\circledast 1$ by Robert A. Cooke (1997) from the manual Leadership/Impact $(B$-measuring the impact of leaders on organizational performance was adopted in this study. This tool Measures the impact of leaders on organizational performance, description by others inventory.

Part 1 - Impact on others and Part 2 - Leadership Strategies of the inventory was adopted for the present investigation.

Impact on others have 96 statements and the inventory uses a five-point scale ( $1=$ Not at all; $5=$ To a very great extent). This measures the influence of leaders with respect to constructive behaviours (32 statements) -the specific Constructive behaviours (32 statements that can be promoted by leaders investigated are 1. Achievement ( 8 statements) 2 . Self-Actualizing (8 statements) 3. Humanistic / Encouraging ( 8 statements) and 4. Affiliative (8 statements).

The specific Passive / Defensive behaviours (32 statements) that can be attributed to leaders are 1. Approval (8 statements) 2. Conventional (8 statements) 3. Dependent (8 statements) and 4. Avoidance (8 statements).

The specific Aggressive / Defensive behaviours (32 statements) that can be promoted by leaders are 1. Oppositional (8 statements) 2. Power (8 statements) 3. Competitive (8 statements) and 4. Perfectionistic (8 statements).

Leadership Strategies ${ }^{2}$ : The extent to which managers personally act in Prescriptive versus Restrictive ways. Leadership strategies have 60 statements and the inventory uses a five-point scale ( $1=$ Never; $5=$ Always). Restrictive strategies (30 statements) and Prescriptive strategies (30 statements). This is divided into 2 domains (12 statements) for the Restrictive and Prescriptive behaviours in the Personal category. 5 domains (30 statements) for the Restrictive and Prescriptive behaviours in the Interpersonal category. 5 domains (18 statements) for the Restrictive and Prescriptive behaviours in the Organizational category. 


\begin{tabular}{|l|l|l|l|}
\hline Domain & Restrictive & Prescriptive & Level \\
\hline Envisioning & Delimiting & Defining & Personal \\
Role Modeling & Circumscribing & Exemplifying & Personal \\
Mentoring & Passive & Active & Interpersonal \\
Stimulating Thinking & Vertical & Lateral & Interpersonal \\
Referring & Negative Referents & Positive Referents & Interpersonal \\
Monitoring & By Exception & By Excellence & Interpersonal \\
Providing Feedback & Negative & Positive & Interpersonal \\
Reinforcing & Punishment & Reward & Organizational \\
Influencing & Unilateral & Reciprocal & Organizational \\
Creating a Setting & Constraining & Facilitating & Organizational \\
& Defensive & Constructive & \\
& Impact & Impact & \\
\hline
\end{tabular}

Fig 1: Diagrammatical list of Leadership/Impact®) items (From Leadership/Impact ${ }^{\circledR}$ Feedback Report by R.A. Cooke, Human Synergistics. Copyright (C) 2008 by Human Synergistics International. Adapted by permission.

1 Leadership/Impact $\mathbb{B}^{\circ}$ is a registered trademark of Human Synergistics International.

2 All Leadership/Impact $($ leadership strategy descriptions: From Leadership/Impact@ Feedback Report by R.A. Cooke, Human Synergistics. Copyright (c) 2008 by Human Synergistics International. Adapted by permission.

3 All Leadership/Impact@ style names and descriptions: From Leadership/Impact@ Feedback Report by R.A. Cooke, Human Synergistics. Copyright 2008 by Human Synergistics International. Adapted by permission.

\section{Data Analysis and Findings}

Respondent profile: The distribution of respondents along demographic variables was as follows: $60 \%$ of the respondents were junior level executives, $28 \%$ were managers and $12 \%$ were senior managers. $50 \%$ of the respondents supervised more than $1-5$ employees, $35 \% \quad 6-10$ and $15 \%$ more than 10 employees. For $52 \%$ of the respondents this was their first organization whereas for $16 \%$ this was their second organization, $20 \%$ third 
organization and $4 \%$ have worked in 4 not exceeding 8 organizations. $80 \%$ of the respondents were male and $20 \%$ female. $52 \%$ of the respondents were below between $21-25$ years of age, $24 \%$ were between $26-30$ years of age, $16 \%$ were between $31-35$ years and $8 \%$ were in the age group $41-45$ years. $4 \%$ of the respondents were diploma holders, $64 \%$ had completed a bachelors degree, $28 \%$ masters degree and $4 \%$ other professional certificates/courses. $72 \%$ of the respondents were unmarried, $24 \%$ married, $4 \%$ divorced or widowed. $28 \%$ of the respondents had less than one year of work experience, $36 \% 1-3$ years, $8 \% 3-5$ years, $8 \%$ $5-7$ years, $12 \% 7-9$ years and $8 \%$ had above 9 years work experience. $40 \%$ of the respondents held the present position for less than a year, $44 \%$ for $1-3$ years, $4 \%$ for $3-5$ years, $8 \%$ for $5-7$ years, and $4 \%$ for 7 -9 years. $52 \%$ of the respondents knew and worked with the present boss for a year, $28 \%$ for $1-3$ years, $8 \%$ for $3-5$ years, $8 \%$ for $7-9$ years and $4 \%$ above 11 years.

Respondent's perception of managers power bases (Table 1): Indian managers in I.T organizations leverage Legitimate power base which refers to the capacity to impose a sense of obligation or responsibility on another followed by Referent power - the ability to provide others with feelings of personal acceptance, approval, efficacy, or worth, Credibility power - the ability to rely on the person, is credible, follows trough what one said and tells the truth, Expert power - the ability to provide another with needed information, knowledge, or expert advice, Reward power - the capacity to provide others with things they desire or value and the last being Coercive power - the ability to take away rewards and privileges or administer sanctions and punishments.

Respondent's perception of managers leadership strategies (Table 2): Indian I.T managers adopt Prescriptive leadership strategies more than restrictive strategies. They basically believe in strategies that guide or direct the activities and behaviours of employees toward goals, opportunities and methods as compared to strategies which constrain or prohibit activities and behaviours with respect to goals, opportunities and methods. Prescriptive leadership strategies provide employees with a direction to channel their efforts, models regarding how things should be done, positive reinforcement to encourage the repetition of desired behaviours, and a set of parameters specifying their sphere of influence. This strategy is followed by Restrictive leadership strategies which provides employees with directions that should not be pursued, models regarding behaviours they should avoid, negative 
feedback to discourage the repetition of undesired behaviours, and a set of parameters restricting their sphere of influence.

The leadership strategies adopted by Indian managers are Prescriptive Organizational domains that include reinforcing, influencing and creating a setting. The strategies were reward, reciprocal and facilitating, followed by Prescriptive - Interpersonal domains that include mentoring, stimulating thinking, referring, monitoring and providing feedback. The strategies were active, lateral, positive referents, by excellence and positive, Prescriptive Personal domains that include envisioning and role modeling. The strategies were defining and exemplifying. The strategies that followed the prescriptive ones were Restrictive - Personal domains that include envisioning and role modeling. The strategies were delimiting and circumscribing, followed by Restrictive - Interpersonal domains that include mentoring, stimulating thinking, referring, monitoring and providing feedback. The strategies were passive, vertical, negative referents, by exception and negative, Restrictive Organizational domains that include reinforcing, influencing and creating a setting. The strategies were punishment, unilateral, and constraining. The detail means and std. deviation is exhibited in Table 3.

Respondent's perception of managers leadership strategies impact on employees (Table 4): Indian manager's leadership strategies has a Constructive Impact on I.T employees' behaviours. This means that the impact has encouraged and motivated employees' to relate to others and approach their work in ways that have helped them to personally meet higher order needs for growth and satisfaction. The specific behaviours were (1) Achievement-motivates and encourage employees' to set challenging but realistic goals, establish plans to reach goals, and pursue them with enthusiasm, (2) Self-Actualizing-motivates and encourages employees' to gain enjoyment from their work, develop themselves professionally, and approach problems with interest, creativity and integrity, (3) Humanistic/ Encouraging-motivates and encourages employees' to be supportive of others, help those around them to grow and develop, and provide others with positive feedback, and (4) Affiliative- motivates and encourages employees' to treat people as members of the team, be sensitive to the needs of others, and interact in a friendly and cooperative ways.

The constructive impact was followed by Passive/Defensive Impact that drives and reinforces employees' to interact with others around them in selfprotective ways that will not threaten their own security. The specific behaviours 
were (1) Approval-motivates and requires employees' to gain the approval of those around them, 'go along' with people, and maintain (superficially) pleasant interpersonal relationships, (2) Conventional- motivates and requires employees' to conform, fit into the 'mold' and follow rules, policies, and standard operating procedures, (3) Dependent- motivates and requires employees' to do only what they are told, clear all decisions with superiors, and please those in positions of authority, and (4) Avoidance-motivates and requires employees' to avoid any possibility of being blamed for mistake, shift responsibilities to others, and maintain a low profile.

The passive/defensive impact was followed by Aggressive/Defensive Impact that drives and motivates employees' to approach their task-related activities in forceful ways to protect their status and security. The specific behaviours were (1) Oppositional-motivates and drives employees' to point out mistakes, gain status by being critical, and dismiss even good ideas due to minor flaws, (2) Power- motivates and drives employees' to act forceful and aggressive, control the people around them, and build up their power base, (3) Competitive- motivates and drives employees' to operate in a 'win/lose' framework, outperform their peers, and do anything that looks good, (4) Perfectionistic- motivates and drives employees' to set unrealistically high goals, stay on top of every detail, and work long hours to atiain narrowly defined objectives.

\section{Implications of the Study on I.T Employees' Behavior}

- There is a need to be aware of the power bases in the management process and how they will be understood by employees.

- Managers leadership strategies at all levels have an influence on employees' behaviour. The leadership strategies managers adopt should continue to be in the direction of motivating employees and harnessing their energies.

- Managers should not adopt restrictive strategies and coercive power base.

- Managers can and do influence employee attitudes and expectations, by the power bases they adopt and the leadership strategies. 
- When managers are willing to adopt prescriptive strategies and adopt legitimate, referent and credibility power bases on employees, employees are willing to put themselves out for the organization.

- If I.T organizations want more commitment from employees, they will need to see that managers engage in more transformational leadership styles than transactional.

- Any argument about managers adopting restrictive leadership strategies in the face of fierce competition in global markets will only lead to passive/ defensive and aggressive/defensive behaviours from employees.

- The power bases and leadership strategies must be in relation to information and development with respect to opportunities for promotion of employees.

- The power bases and leadership strategies are likely to vary in large organizations.

- Effective utilization of power bases and the leadership strategies are more likely to have a positive impact on I.T employees where HR practices are applied, where effective job-related and induction related communication takes place.

- Research indicates that managerial power processes, leadership strategies and its impact is a fit case for careful management attention and reflected in the use of human resource management practices of I.T organizations.

- The study also implies that careful management of the power bases and the leadership strategies makes a positive contribution to effective employment relations and impact on I.T employees.

Though at the general psychological level, power corrupts but it also uplifts life. At the sociological level, power is both integrative and divisive. The study of power and leadership as it exists in organizations is a must as society without a power structure is inconceivable and humans cannot function fully with their leadership potential untapped and one's power motive castrated. 


\section{Conclusion}

The Power base most frequently used was legitimate followed by referent power base. Prescriptive leadership strategies were more preferred than Restrictive strategies. impact of leadership was Constructive followed by Passive/Defensive and Aggressive/Defensive Though at the general psychological level, power corrupts but it also uplifts life. At the sociological level, power is both integrative and divisive. The study of power and leadership as it exists in organizations is a must as society without a power structure is inconceivable and humans cannot function fully with their leadership potential untapped and one's power motive castrated.

\section{References}

Anderson, D. A. (1998, December). Using power and influence tactics for better results. Marine Corps Gazette, pp. 37-38.

Anderson, J. A. (1999). Are power motivated leaders more effective? A review of

Bachrach, P. \& Baratz, M. S. (1962). The two faces of power. American Political Science Review, 56, 947-952.

Bass, B. M. (1985). Leadership and performance beyond expectations. New York: The Free Press.

Bass, B. M. (1981). Power and leadership. In Stogdill's handbook of leadership: A survey of theory and research (Rev. ed., pp. 169-191). New York: Macmillan Publishing.

Clements, C., \& Washbush, J. B. (1999). The two faces of leadership: Considering the dark side of leader-follower dynamics. Journal of Workplace Learning, 11(5), 170-176.

Conger, J. (1997). The dark side of leadership. In R. P. Vecchio (Ed.), Leadership: Understanding the dynamics of power and influence in organizations (pp. 215-232). Notre Dame, IL: University of Notre Dame Press.

Clegg, S. R. (1979). The theory of power and organization. London: Routledge and Kegan Paul.

Clegg, S. R. (1989). Frameworks of power, London: Sage.

Dahl, R. A. (1957). The concept of power. Behavioral Science, 2, 201-215.

Daudi, P. (1986). Power in the organization: The discourse of power in managerial praxis. Oxford: Basil Blackwell. 
French, J. R. P. \& Raven, B. (1959). The bases of social power. In D. Cartwright, Studies in social power, (pp. 150-167). Anne Arbour: University of Michigan Institute for Social Research.

French, J. R. P. (1964). Laboratory and field studies of power. In R. L. Kahn \& E. Boulding (Eds.). Power and conflict in organizations (pp. 33-51). London: Tavistock.

Hiley, D. R. (1987). Power and values in corporate life. Journal of Business Ethics, 6, 343353.

Hollander, E. P., \& Offermann, L. R. (1990). Power and leadership in organizations. American Psychologist, 45(2), 179-189.

House, R. J., \& Baetz, M. (1979). Leadership: Some empirical generalizations and new research directions. In B. M. Staw (Ed.), Research in organizational behavior (Vol. 1, pp. 34 1-423). Greenwich, CT: JAI Press.

Kahn, R. L. (1964). Introduction. In R. L. Kahn \& E. Boulding (Eds.). Power and conflict in organizations. (pp. 1-10). London: Tavistock.

Kanter, R. M. (1981). Power, leadership, and participatory management. Theory into Practice $21,219-228$.

Kipnis, D. (1984). The use of power in organizations and in interpersonal settings. Applied Social Psychology Annual, 5, 179-210.

Kipnis, D., Castell, J., Gergen, M., \& Mauch, D. (1976). Metamorphic effects of power. Journal of Applied Psychology, 61 (2), 127-135.

Kipnis, D., \& Vanderveer, R. (1971). Ingratiation and the use of power. Journal of Personality \& Social Psychology, 17(3), 280-286.

Knights, D. \& Roberts, J. (1982). The power of organisation or the organisation of power. Organisation Studies, $3(1), 47-63$.

Kotter, J. P. (1979). Power in management, New York: Amacon.

Mani. S.S. (1988). An organizational culture approach to the study of individual power and its uses. Ph.D. thesis, 1988. As abstracted in the dissertation abstracts international Ahumanities and social sciences, 1988 (Oct), Vol 49 (4).

McClelland, D. C. (1970). The two faces of power. Journal of International Affairs, 24(2), 29- 47.

McClelland, D. C. (1975). Power: The inner experience. New York: Irvington.

Medina, J. Francisco \& Munduate, Lourdes, (2004). Power, Authority, and Leadership, Encyclopedia of Applied Psychology, APSY 00348 1, VOLUME X, 2004.

Mintzberg, H. (1983). Power in and around organizations. Englewood Cliffs, NJ: Prentice Hall. 
Ng, S. H. (1980). The social psychology of power. London: Academic Press.

O'Neal, E. C., Kipnis, D., \& Craig, K. M. (1994). Effects on the persuader of employing a coercive influence technique. Basic and Applied Social Psychology, 15(3), 225-238.

Pareek, U.A (1971-76). Survey of research in psychology part-2. 1971-1976. ICCSR New Delhi. Popular Prakashan, Bombay

Pfeffer, J. (1981). Power in organizations. Marshfield, MA: Pitman. Podsakoff, P. M., \& Schriesheim, C. A. (1985). Field studies of French and Raven's bases of power: Critique, reanalysis, and suggestions for future research. Psychological Bulletin, 97, 387-411.

Rahim, M. A., Antonioni, D., Psenicka, C., Kim, N. H., \& Khan, A. A. (1999). Bases of Raven, B. H. (1992). A power/interaction model of interpersonal influence: French and Raven thirty years later. Journal of Social Behavior and Personality, 7(2), 217-244.

Raven, B. H. (1965). Social influence and power. In I. D. Steiner \& M. Fishbein (Eds.), Current studies in social psychology (pp. 371-382). New York: Holt, Rinehart, \& Winston.

Singh, S.B. (1986.1987). Behavioural strategies for influencing immediate superiors. Psychologia: An International Journal of Psychology in the orient, 1986 (Mar), Vol 31 (1), 3441. As abstracted in the American psychological abstracts, 1987 (Apr). Vol 76 (4).

Singh, R.P and Pandey, J. (1988). Choosing a base of power through routinized rewards. Vikalpa, 1988 (Jan-Mar), Vol 13 (1), 63-67.

Sinha, J.B.P. (1982) Power in Indian Organizations. Indian Journal of Indusirial Relations, 1982, Vol 17,339-352.

Yukl, G. (1998). Leadership in Organizations (4th ed.). Upper Saddle River, NJ: PrenticeHall.

Wrong, D. (1979). Power: Its forms, bases and uses. Oxford: Basil Blackwood. 


\section{Appendix}

Table 1: Indicating the mean and S.D on the Six Power Bases of bosses.

\begin{tabular}{|l|c|c|}
\hline Power Bases & Mean & Std. Deviation \\
\hline Legitimate & 5.37 & 1.81 \\
Referent & 5.12 & 1.70 \\
Credibility & 5.06 & 1.68 \\
Expert & 5.06 & 1.71 \\
Reward & 4.59 & 1.70 \\
Coercive & 3.11 & 1.58 \\
\hline
\end{tabular}

Table 2: Indicating the mean and S.D on Prescriptive and Restrictive Leadership Strategies adopted by bosses.

\begin{tabular}{|l|c|c|}
\hline Leadership Strategies & Mean & Std. Deviation \\
\hline Prescriptive & 3.38 & 1.10 \\
Restrictive & 3.02 & 0.54 \\
Prescriptive (Organizational) & 3.42 & 1.11 \\
Prescriptive (Interpersonal) & 3.38 & 1.09 \\
Prescriptive (Personal) & 3.30 & 1.19 \\
Restrictive (Personal) & 3.28 & 0.93 \\
Restrictive (Interpersonal) & 3.01 & 0.57 \\
Restrictive (Organizational) & 2.88 & 0.56 \\
\hline
\end{tabular}


Table 3: Indicating the mean and S.D on the leadership strategies adopted by bosses.

\begin{tabular}{|c|c|c|}
\hline Leadership Strategies & Mean & Std. Deviation \\
\hline Active (Prescriptive-Interpersonal-Mentoring) & 3.53 & 1.12 \\
\hline $\begin{array}{l}\text { By Excellence (Prescriptive-Interpersonal } \\
\text {-Monitoring) }\end{array}$ & 3.52 & 1.20 \\
\hline $\begin{array}{l}\text { Positive (Prescriptive-Interpersonal } \\
\text {-Providing feedback) }\end{array}$ & 3.50 & 1.30 \\
\hline $\begin{array}{l}\text { Reward (Prescriptive-Organizational } \\
\text {-Reinforcing) }\end{array}$ & 3.48 & 1.26 \\
\hline $\begin{array}{l}\text { Reciprocal (Prescriptive-Organizational } \\
\text {-Influencing) }\end{array}$ & 3.40 & 1.04 \\
\hline $\begin{array}{l}\text { Facilitating (Prescriptive- Organizational } \\
\text {-Creating a setting) }\end{array}$ & 3.40 & 1.22 \\
\hline $\begin{array}{l}\text { Lateral (Prescriptive-Interpersonal } \\
\text {-Stimulating thinking) }\end{array}$ & 3.33 & 1.31 \\
\hline $\begin{array}{l}\text { Circumscribing (Restrictive-Personal } \\
\text {-Role modeling) }\end{array}$ & 3.32 & 1.07 \\
\hline $\begin{array}{l}\text { Vertical (Restrictive-Interpersonal } \\
\text {-Stimulating thinking) }\end{array}$ & 3.31 & 0.78 \\
\hline $\begin{array}{l}\text { Exemplifying (Prescriptive-Personal } \\
\text {-Role modeling) }\end{array}$ & 3.30 & 1,23 \\
\hline Defining (Prescriptive-Personal-Envisioning) & 3.30 & 1.20 \\
\hline Delimiting (Restrictive-Personal- Envisioning) & 3.25 & 0.96 \\
\hline $\begin{array}{l}\text { By Exception (Restrictive-Interpersonal } \\
\text {-Monitoring) }\end{array}$ & 3.13 & 0.92 \\
\hline $\begin{array}{l}\text { Constraining (Restrictive-Organizational } \\
\text {-Creating a setting) }\end{array}$ & 3.04 & 0.83 \\
\hline $\begin{array}{l}\text { Positive referents (Prescriptive } \\
\text {-Interpersonal-Referring) }\end{array}$ & 3.03 & 0.97 \\
\hline $\begin{array}{l}\text { Negative referents (Restrictive } \\
\text {-Interpersonal-Referring) }\end{array}$ & 3.00 & 0.58 \\
\hline $\begin{array}{l}\text { Unilateral (Restrictive-Organizational } \\
\text {-Influencing) }\end{array}$ & 2.96 & 0.77 \\
\hline $\begin{array}{l}\text { Passive (Restrictive-Interpersonal } \\
\text {-Mentoring) }\end{array}$ & 2.84 & 0.75 \\
\hline $\begin{array}{l}\text { Negative (Restrictive-Interpersonal } \\
\text {-Providing feedback) }\end{array}$ & 2.78 & 0.78 \\
\hline $\begin{array}{l}\text { Punishment (Restrictive-Organizational } \\
\text {-Reinforcing) }\end{array}$ & 2.65 & 0.83 \\
\hline
\end{tabular}


Table 4: Indicating the mean and S.D on the leadership Impact of bosses.

\begin{tabular}{|l|c|c|}
\hline \multicolumn{1}{|c|}{ Leadership Strategies Impact } & Mean & Std. Deviation \\
\hline Constructive Impact & 3.23 & 1.06 \\
Passive/Defensive Impact & 2.60 & 0.55 \\
Aggressive/Defensive Impact & 2.57 & 0.73 \\
Achievement (Constructive) & 3.40 & 1.56 \\
Self-Actualizing (Constructive) & 3.20 & 0.94 \\
Affiliative (Constructive) & 3.19 & 1.02 \\
Humanistic (Constructive) & 3.16 & 1.02 \\
Conventional (Passive/Defensive) & 2.87 & 0.70 \\
Power (Aggressive/Defensive) & 2.80 & 0.75 \\
Dependent (Passive/Defensive) & 2.68 & 0.59 \\
Perfectionistic (Aggressive/Defensive) & 2.62 & 0.81 \\
Competitive (Aggressive/Defensive) & 2.47 & 0.99 \\
Avoidance (Passive/Defensive) & 2.45 & 0.66 \\
Approval (Passive/Defensive) & 2.40 & 0.67 \\
Oppositional (Aggressive/Defensive) & 2.40 & 0.67 \\
\hline
\end{tabular}

